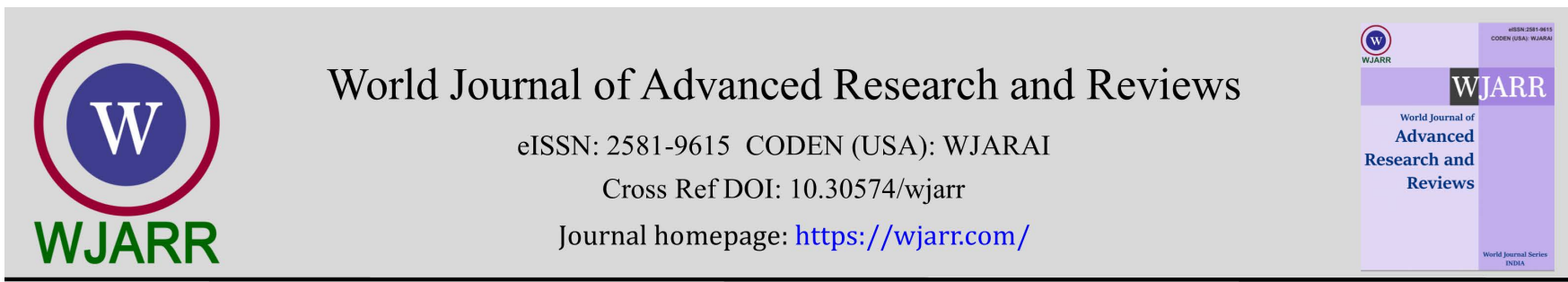

(RESEARCH ARTiClE)

Check for updates

\title{
Gypsum amendment and seasonal variability: effect on soil quality, fruit characteristics and toxicological responses of Cucumber (Cucumis sativus l.) in the Ahafo-Kenyasi Mining Area of Ghana
}

\author{
Kwaku Onwona-Hwesofour Asante 1, 2, *, Simon Abugri 2, Nana Sarfo Agyemang Derkyi ${ }^{2}$ and Daniel Sarfo \\ Akoto $^{2}$
}

${ }^{1}$ Agency for Health and Food Security, South Suntreso, Kumasi, Ghana.
2 University of Energy and Natural Resources, Sunyani, Ghana.

World Journal of Advanced Research and Reviews, 2021, 09(03), 229-244

Publication history: Received on 19 January 2021; revised on 06 March 2021; accepted on 08 March 2021

Article DOI: https://doi.org/10.30574/wjarr.2021.9.3.0053

\begin{abstract}
Depending on soil, climate and crop characteristics exposed subsoils can be amended with gypsum for agricultural activities when topsoil is inadequate as a result of natural and geophysical activities. To determine how exposed subsoil amendment with gypsum interact with weather patterns to influence soil chemical properties, cucumber growth, fruit characteristics and heavy metal concentration, a two-seasonal experiment was conducted in the major and minor rainy season of 2020 in the Ahafo-Kenyasi Mining Area in Ghana. The experiment was laid out as a 6x2 factorial arranged in randomized complete block design, consisting of 6 gypsum application rates (20 ton/ha, 40 ton/ha, 60 ton/ha, 80 ton/ha, 0 ton/ha (subsoil control) and 0 ton/ha (topsoil control)) in two rainy seasons and replicated three times. The results show that gypsum application and rainy seasons interact to significantly influence soil chemical properties, cucumber growth and fruit characteristics. Increasing gypsum application resulted in decreased organic carbon, increased calcium, increased available $\mathrm{P}$, increased exchangeable magnesium (Mg), increased pH during both major and minor rainy seasons. Vine length, number of leaves, number of fruits per plant and fruit weight of cucumber were increased with increasing gypsum application during the minor rainy season. In spite of exceeding permissible limits in soils and crops, arsenic (As), cadmium (Cd) and mercury (Hg) showed similar concentrations (below $2 \mathrm{mg} / \mathrm{kg}$ ) in cucumber during the minor and major rainy seasons across gypsum treatments. Lead (Pb) concentration in cucumber was significantly higher in the major season across treatments. There was no difference in lead (Pb) concentration for treated vs untreated, and no increase across the amendment range. Further studies on how heavy metals in soil and plants interact with plant phytochemicals in ecosystems and living tissues are recommended.
\end{abstract}

Keywords: Sustainable mining; Circular economy; Gypsum; Seasonal variability; Heavy metal toxicology

\section{Introduction}

The physicochemical properties of soils drive ecosystem function and vegetation dynamics and hence soil restoration towards reinstating the soil properties and hydrological dynamics of remnant soils after mining [1]. Surface mining disturbs hundreds of hectares of land every year in many areas of the world, thereby altering valuable, ecologicallydiverse forests [2]. During mine closure, the requirement of rich topsoils becomes paramount. However, due to stockpile changes over the course of the mine life; including compaction and erosion, the stockpiles of topsoils are mostly not sufficient for revegetation. Additionally, areas such as the Ahafo Kenyasi and others are naturally low in topsoil probably due to inadequate weathering or extensive and prolonged erosion. The question that remains unanswered is whether

\footnotetext{
* Corresponding author: Kwaku Onwona-Hwesofour Asante; Phone:+233242272347; Email:asante.kwaku@gmail.com Agency for Health and Food Security, South Suntreso, Kumasi. 
exposed subsoils could be amended and used for revegetation after mine closure to facilitate agricultural and forestry activities.

In mining landscapes, reconstructed soils have often transformed soil physical and chemical profiles leading to lower nutrient availability and higher bulk density, unfavorable $\mathrm{pH}$ and electrical conductivity and thereby posing threat to soil-water and nutrient balance, distribution of soil flora and fauna, plant growth, development and food security [1].

The effect of soil compaction can be phenomenal in root growth extension by either retarding root extension or restricting growth altogether. For example, Table 1 presents a relationship between soil texture and bulk density for root growth and extension.

Table 1 General relationship of soil bulk density to root growth based on soil texture.

\begin{tabular}{|c|c|c|c|}
\hline Soil Texture & $\begin{array}{l}\text { Ideal bulk density for } \\
\text { plant growth }\left(\mathrm{g} / \mathrm{cm}^{3}\right)\end{array}$ & $\begin{array}{l}\text { Bulk densities that } \\
\text { affect root growth } \\
\left(\mathrm{g} / \mathrm{cm}^{3}\right)\end{array}$ & $\begin{array}{l}\text { Bulk densities that } \\
\text { restrict root growth } \\
\left(\mathrm{g} / \mathrm{cm}^{3}\right)\end{array}$ \\
\hline Sands, loamy sands & $<1.60$ & 1.63 & $>1.80$ \\
\hline Sandy loams, loams & $<1.40$ & 1.63 & $>1.80$ \\
\hline Sandy clay loams, clay loams & $<1.40$ & 1.60 & $>1.75$ \\
\hline Silt, silt loams & $<1.40$ & 1.60 & $>1.75$ \\
\hline Silt loams, silty clay loams & $<1.40$ & 1.55 & $>1.65$ \\
\hline Sandy clays, silty clays, clay loams & $<1.10$ & 1.49 & $>1.58$ \\
\hline Clays ( $>45 \%$ clay) & $<1.10$ & 1.39 & $>1.47$ \\
\hline
\end{tabular}

Acid rock drainage (ARD) or acid mine drainage (AMD) is the outflow of acidic water from rocks or mines as a result of natural geological activities or large-scale earth disturbances characteristic of large construction and mining activities involving rocks with abundant quantities of sulfide minerals. Upon exposure to water and oxygen, most sulfide minerals in rocks oxidize to form sulfuric acid, metal ions and sulfate, which, if untreated, enter surface or groundwater [4]. One of the most common scales encountered in ARD or AMD type waters used for metal recovery or processing is gypsum $\left(\mathrm{CaSO}_{4} 2_{2} \mathrm{H}_{2} \mathrm{O}\right)$. According to Gibson et al. [5], AMD is a problem in most mines due to high levels of pyrite (FeS2) within the embedded rock and that these ARD waters are often very acidic, have high levels of metals and produce calcium Sulfate (Gypsum) scaling. If not properly treated the risk of generating rapid fouling and scaling of membrane plants can cause catastrophic failure of the membranes. However, for most mines, the mechanism by which the gypsum produced can be disposed of remains a challenge and the questions of whether there are heavy metals in the gypsum produced and how these metals if any react in soils during amendments remain unanswered. Due to the geochemical changes and heavy metal use associated with mining, there is a general perception that soils in mined areas pose a threat to food safety if used for agricultural purposes.

Cucumber is chosen as a test crop for this experiment because of its high sensitivity to changes in soil physicochemical and climatic variability. It has, also, a high affinity for calcium for its structural functions in the cell wall and membrane development [6]. Since gypsum is noted for its high calcium requirement, this experiment could reveal the rate at which gypsum can be used to amend soil for sensitive agricultural commodities. The assumption is that if sensitive crops do well, tolerant and resilient crops would do better. The need for this study in Ghana is further justified by the abundance of minerals in the country and the poor understanding of how circular economy and sustainable mining can be operationalized in handling gypsum during the management of ARD. Information on how gypsum affects soil chemical properties, what rate of application contributes best to plant growth, how subsoils and gypsum contribute to heavy metals in plants among others remain limited. World Bank [7]; Ofori-Sarpong [8]; Ferring and Hausermann [9] among others argue that AMD, heavy metals contamination and landuse changes from natural and mining-related activities can threaten the health and food security in AMD-susceptible areas. In its 2020 Country Environmental Analysis, World Bank [7] established that the cost of environmental degradation associated with mining and other landuse activities to the Ghanaian society is estimated at about US\$6.3 billion, equivalent to 10.7 percent of the country's 2017 GDP.

Globally, interest is increasing in the role of gypsum and cover crops to enhance soil physical and chemical properties, including organic matter content, water infiltration, aggregate stability, nutrient retention, and microbial diversity, 
while decreasing runoff and erosion [10]. To this end, the principles of circular economy and sustainability can be promoted by directing efforts at creating a closed-loop system that enables the reuse, sharing, amending subsoils with the gypsum produced to minimize the use of resource inputs and the creation of waste, pollution and greenhouse gas emissions. The promotion of sustainability is also hinged on circular economy [11]. The practice of circular economy principles is also in line with considerable number of Sustainable Development Goals (SDGs). Notable ones are SDGs 2, $7,11,12,13,14$ and 15.

This study therefore examines how subsoil amendment with different rates of gypsum and seasonal variability influence chemical properties of exposed subsoils and how these changes affect the growth and yield of cucumber and concentration of heavy metals.

\section{Methodology}

\subsection{Experimental site and design}

Two experiments were carried out in the major (May-July 2020) and minor (August-October 2020) rainy seasons at Newmont Ghana Gold Limited's Ahafo Mines in Kenyasi located in the Forest- Savannah transitional zone of Ghana (Lat. $07^{\circ}, 04^{\prime} \mathrm{N}$; Long. 01으, 24’W).

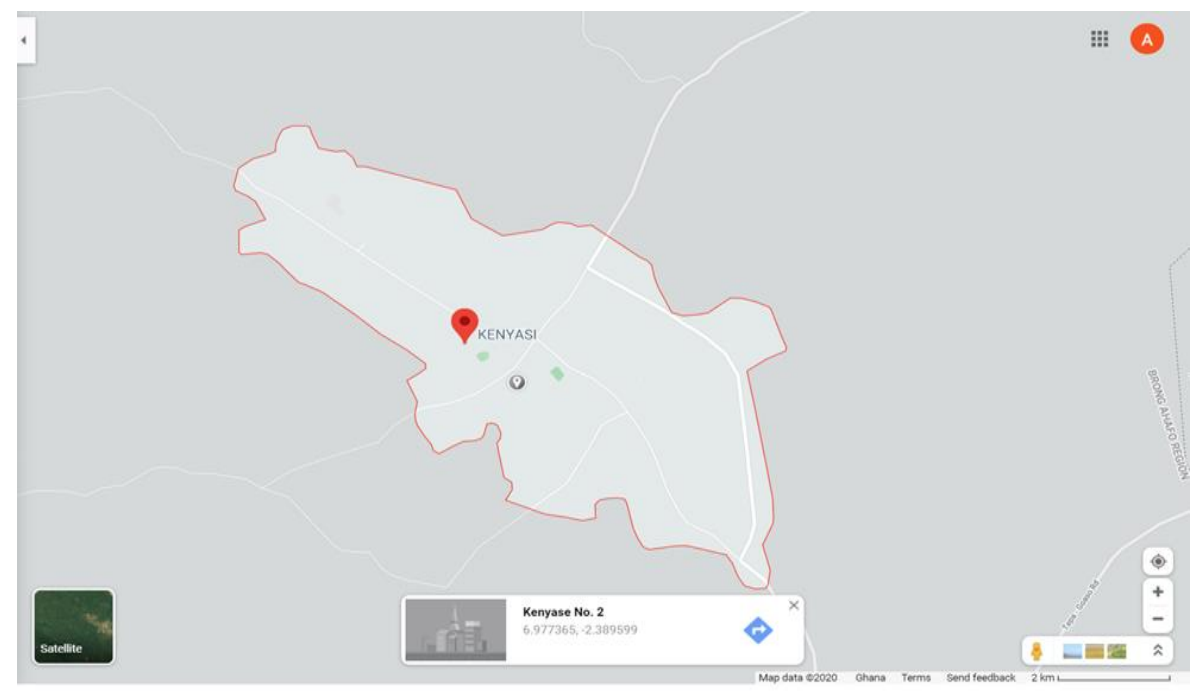

Figure 1 Map of experimental site

The area features low rolling hills and receives modest to fairly high annual rainfall $(1,250-2,000 \mathrm{~mm})$ and lies in the general headwaters of the Tano River Basin.

The experimental design was 6x2 factorial arranged in randomized complete block design comprising 6 (six) rates of gypsum application (20 ton/ha, 40 ton/ha, 60 ton/ha, 80 ton/ha, sub-soil control, topsoil control) and 2 rainy seasons (major and minor). The experiment was replicated three times.

\subsection{Land Preparation and Field Management}

Sub-soil area of $14 \mathrm{~m} \times 8 \mathrm{~m}$ field size and a topsoil area of $8 \mathrm{~m} \times 2 \mathrm{~m}$ were cleared, loosened, leveled and laid out for 5 plots per block measuring $2 \mathrm{~m} \times 2 \mathrm{~m}$ per plot in 3 blocks. The topsoil beds maintained the same plot sizes with three plots for comparative performance. Beds measuring $2 \mathrm{~m} \times 2 \mathrm{~m}$ were raised to $20 \mathrm{~cm}$ height and re-leveled. The path left between each plot and between each block was $1 \mathrm{~m}$.

\subsection{Gypsum Production}

Gypsum used in the experiment was produced by a precipitation process from the concentrate of a reverse osmosis (RO) water treatment plant in which impacted water from the Apensu pit was pumped at a nameplate capacity of $50 \mathrm{~L} / \mathrm{s}$ to the mine water treatment plant (MWTP). The feed was pre-filtered to exclude particle sizes greater than $200 \mu \mathrm{m}$ going to the ultra-filtration (UF). The pre-filtration includes the pe-filters and an inline mixer for sodium hypochlorite dosing for feed water disinfection. 
Desalination was done in two 2-stage RO trains. The first stage of each train is referred to as the lead bank, and the second stage is referred to as the concentrate bank. Antiscalant is dosed inline upstream of lead and concentrate banks to prevent scale formation as the mineral saturation indices increase along the element string. Sodium bisulphite (SBS) was dosed upstream of the lead bank of each RO train for free chlorine control. Volumetric recovery over the combined banks on each train was deployed by a flow control valve on the brine discharge line.

The remaining part of the feed water was rejected from the primary RO plant as a brine stream which is unstable with respect to calcite and gypsum. The process produced the following products and waste streams:

- A brine treatment RO (BT RO) permeate stream which can be blended with the primary RO permeate stream for release into the environment if ammonia-N concentration permit;

- A chemically stable treated BT RO concentrate stream;

- A stable gypsum sludge is stored in a lined pond.

\subsection{Gypsum storage and soil amendment rate}

From two gypsum ponds of $8000 \mathrm{~m}^{3}$ lined with high density polyethylene (HDPE) each, the brine decant was transferred back to the effluent tank after gypsum settling. The gypsum obtained was applied to the exposed subsoils at rates 20 ton/ha, 40 ton/ha 60 ton/ha 80 ton/ha, 0 ton/ha (exposed subsoil control) and 0 ton/ha (topsoil control).

\subsection{Soil physical properties}

Data on gravimetric moisture content, total porosity and bulk density were determined using methods described in Asante et al. [12]. The soil samples were taken by driving aluminum core sampler of known volumes into the soil at 0$15 \mathrm{~cm}$ depth prior to gypsum amendment and 12 weeks after amendment. Samples taken from each plot were then oven-dried at $105^{\circ} \mathrm{C}$ to a constant weight. The following relations were used to determine the physical characteristics;

Bulk density

$$
\text { Bulk density }=\frac{\text { Weight of oven dry soil }}{\text { Volume of Soil }}
$$

Soil porosity was determined using the formula $f=\frac{1-B D}{P D} X 100$

Where $\mathrm{f}=$ Total porosity $\mathrm{BD}=$ bulk density $\mathrm{PD}=$ particle density $=2.65 \mathrm{~g} / \mathrm{cm}^{3}$

Gravimetric moisture was then calculated by using the formula;

$$
(\theta) g=\frac{M 1-M 2}{M 2} \times 100
$$

Where $\theta \mathrm{g}$ is soil gravimetric moisture; $\mathrm{M}_{1}$ is the weight of soil before oven drying; $\mathrm{M}_{2}$ is the weight of soil after ovendrying [12].

\subsection{Soil chemical and heavy metal assessment}

Soil samples were randomly taken from 5 spots in each plot at a depth of $0-15 \mathrm{~cm}$ and bulked before sub-sampling for analysis two weeks before treatment application and two weeks after treatment application.

Electrometric method was used to determine the soil $\mathrm{pH}$ [13]. Available P was determined by Acid Fluoride Extraction procedure (Bray-1 Method) [14]. Kjeldahl method was used to determine total N [14]. Exchangeable bases (K, Ca, Mg and $\mathrm{Na}$ ) were determined by the ammonium acetate $\left(\mathrm{NH}_{4} \mathrm{OAc}\right)$ extraction method [15]. Exchangeable acidity ( $\mathrm{H}$ and $\mathrm{Al}$ ) was also determined by titration of soil extracts to a phenolphthalein endpoint [6].

Organic carbon was determined by Walkley-Black Wet Oxidation Method (Cater et al., 2007). Organic matter content was determined using the formula: \% Organic Matter= \% organic C X 1.724. (1.724 is the Van Bemellean factor). Particle size distribution (clay, silt, sand) was assessed by the hydrometer method [17]. 


\subsection{Growth and Yield Assessment}

Vegetative parameters were assessed at 2, 4, 6, 8 and 10 weeks after sowing. Cucumber vine length was measured by using a flexible tape rule. The number of leaves was assessed by visual count of the green leaves.

Harvest was done when fruits reached commercial maturity and weekly thereafter for a total of 4 harvests. On each of the 18 experimental plots, one fruit taken from the second harvest was used for fruit physical and chemical quality assessments. The fruit length was measured with a $30 \mathrm{~cm}$ rule. The number of fruits was visually ascertained. Fruit weight was determined with 5000-gram scale. After the second harvest, concentrations of heavy metals (Cd, Pb, As and $\mathrm{Hg}$ ) were determined from atomic absorption spectrophotometer for the various metals at specified wavelengths [18].

\subsection{Data analysis}

Data collected were analyzed with GenStat software package 2008 version 11.1. A two-way Analysis of Variance (ANOVA) was conducted with levels of gypsum as treatment factor 1 and season as treatment factor 2 . Means were separated using standard error of differences at a 5\% significance level.

\section{Results and discussion}

\subsection{Physicochemical and climatological description of experimental site and materials used}

Bulk density, porosity and moisture content of topsoil and exposed subsoil remained ideal for root growth during the major and minor season (Table 2).

Table 2 Pre-treated soil characteristics

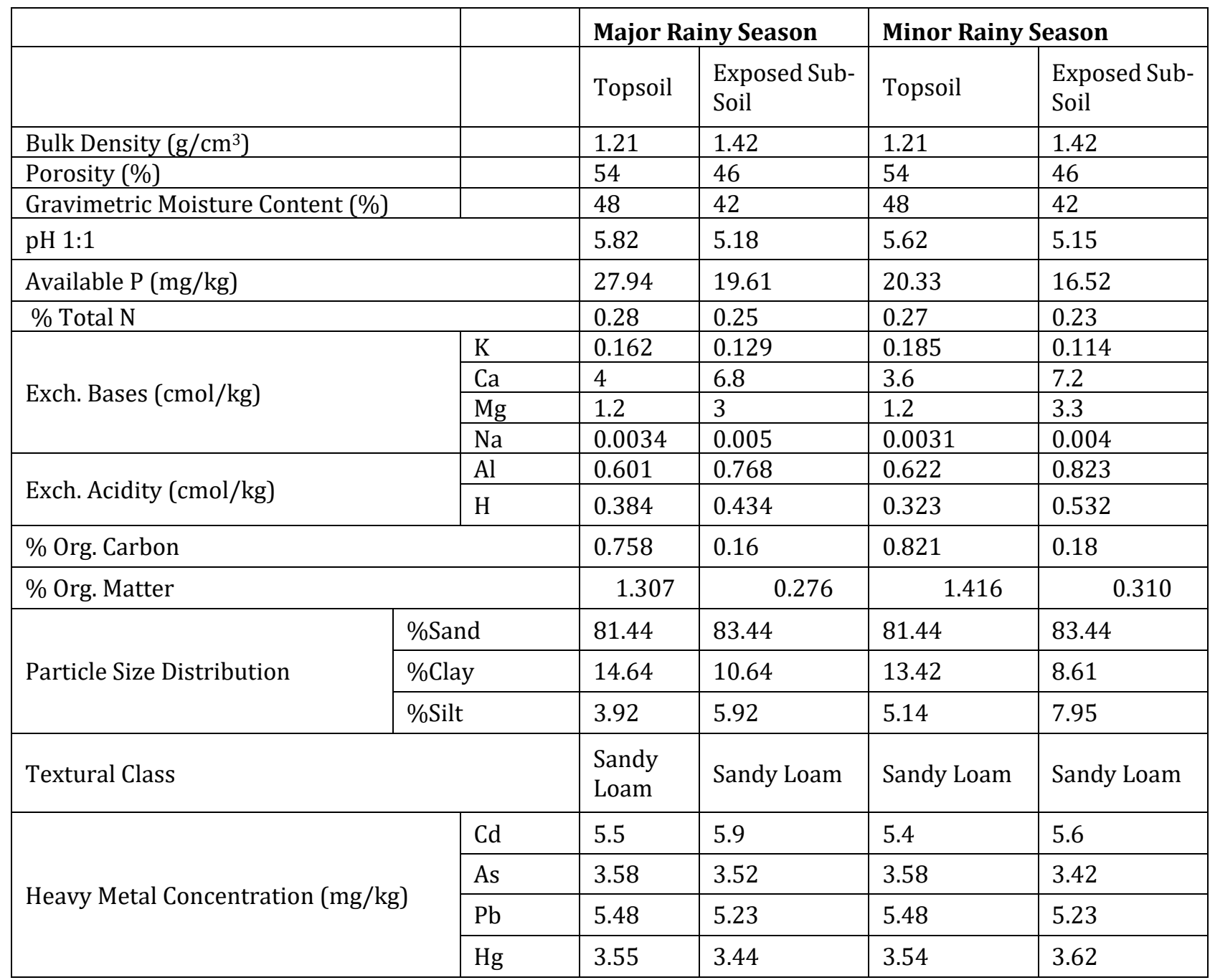


The $\mathrm{pH}$ for the top was moderately acidic whereas the subsoil remained very acidic. Available $\mathrm{P}$ remained high for topsoil and moderate for subsoil. Percentage $\mathrm{N}$ in both top and subsoils were high during the major and minor rainy seasons. $\mathrm{K}, \mathrm{Ca}, \mathrm{Mg}$ and $\mathrm{Na}$ remained very low, low, low and suitable respectively for both top and subsoil during the major and minor rainy seasons. Percentage organic carbon and organic matter were low for both top and subsoils during the major and minor seasons (Reference scale in Appendix 1). On the whole heavy metals on the experimental site for top and sub-soils were higher for arsenic (As) and cadmium (Cd) than the FAO/WHO normal values. Mercury and Lead concentration in both top and subsoils were considerably lower than the target values in soil during the major and minor rainy seasons (Table 5).

The major rainy season received considerably lower rainfall compared to the minor rainy season. Maximum and minimum temperatures were higher in the major season than the minor season. Relative humidity (RH) was lower in the major rainy season than the minor season (Table 3).

Table 3 Weather information during experimental period.

\begin{tabular}{|c|c|c|c|c|c|c|}
\hline \multirow{2}{*}{ Parameters } & \multicolumn{3}{|c|}{ Major Rainy Season } & \multicolumn{3}{|c|}{ Minor Rainy Season } \\
\hline & May & June & July & August & September & October \\
\hline Rainfall (mm) & 136 & 199.1 & 31.7 & 17.3 & 250.3 & 246.8 \\
\hline Temp. $\operatorname{Max}\left({ }^{\circ} \mathrm{C}\right)$ & 32.5 & 30.1 & 28.3 & 28.7 & 29.7 & 30.7 \\
\hline Temp. Min $\left({ }^{\circ} \mathrm{C}\right)$ & 23.2 & 22.1 & 21.5 & 19.6 & 20.7 & 20.9 \\
\hline RH@0600Z & 92 & 94 & 93 & 93 & 95 & 94 \\
\hline RH @1500Z & 58 & 66 & 70 & 71 & 69 & 65 \\
\hline
\end{tabular}

Heavy metal concentration of gypsum used in experiment were considerably lower than target value for agricultural soils (Tables 4 and 5).

Table 4 Heavy metal concentration of gypsum.

\begin{tabular}{|l|l|l|l|l|}
\hline & As (mg/kg) & Pb (mg/kg) & Cd(mg/kg) & Hg(mg/kg) \\
\hline Gypsum & 0.0256 & 0.0354 & 0.0547 & 0.0158 \\
\hline
\end{tabular}

Table 5 Normal and Permissible levels of Heavy Metals in Soil and Vegetables.

\begin{tabular}{|l|l|l|l|}
\hline Elements & $\begin{array}{l}\text { Target Value* in } \\
\text { Soil }(\mathbf{m g} / \mathbf{k g})\end{array}$ & $\begin{array}{l}\text { Permissible Value in } \\
\text { vegetables } \mathbf{( m g / k g )}\end{array}$ & Reference \\
\hline $\mathrm{As}$ & 0.5 & 0.1 & {$[19] ;[20]$} \\
\hline $\mathrm{Cd}$ & 0.8 & 0.1 & {$[19] ;[21]$} \\
\hline $\mathrm{Hg}$ & 6.6 & 0.03 & {$[19] ;[22]$} \\
\hline $\mathrm{Pb}$ & 85 & 0.2 & {$[21]$} \\
\hline
\end{tabular}

\subsection{Effect of gypsum-amended soils and seasonal variability on soil chemical characteristics}

Interaction effects between gypsum-amended soils and season were significant for \% organic C, \% organic matter, \% total nitrogen and aluminium (Figure 2). Consequently, the minor season saw increased organic C, organic matter and Al concentration. Total nitrogen content was significantly higher in the major season than the major season except for the subsoil control. Increased levels of gypsum resulted in a decreased organic carbon and organic matter content for both major and minor rainy seasons. The reduction of organic $\mathrm{C}$ and organic matter with increasing gypsum content can 
be attributed to reduced microbial activities and increased mineral concentration of calcium and sulphate ions [23]. Abdel-Fattah [24] argues that the decrease in soil organic carbon and organic matter may be due to enhanced solubility of gypsum because of the increased activity coefficient of calcium and sulfate resulting from increased ionic strength of solution and the formation of the sodium sulfate ion pair. Seasonal differences may be attributed to increased precipitation received during the minor rainy season. The change in precipitation activities where minor rainy seasons appears to exceed major rainy season in precipitation and humidity is largely due to heightened seasonal variability as a result of climate change. Botha et al. [25] argue that climate change prediction models forecast changes in rainfall patterns and rising temperature regimes, negatively impacting soil chemical characteristics and food security. Jansson and Hofmockel [26] found that warmer temperatures during some seasons are predicted to result in increased microbial mineralization of stable soil organic matter and a corresponding increased CO2 flux.
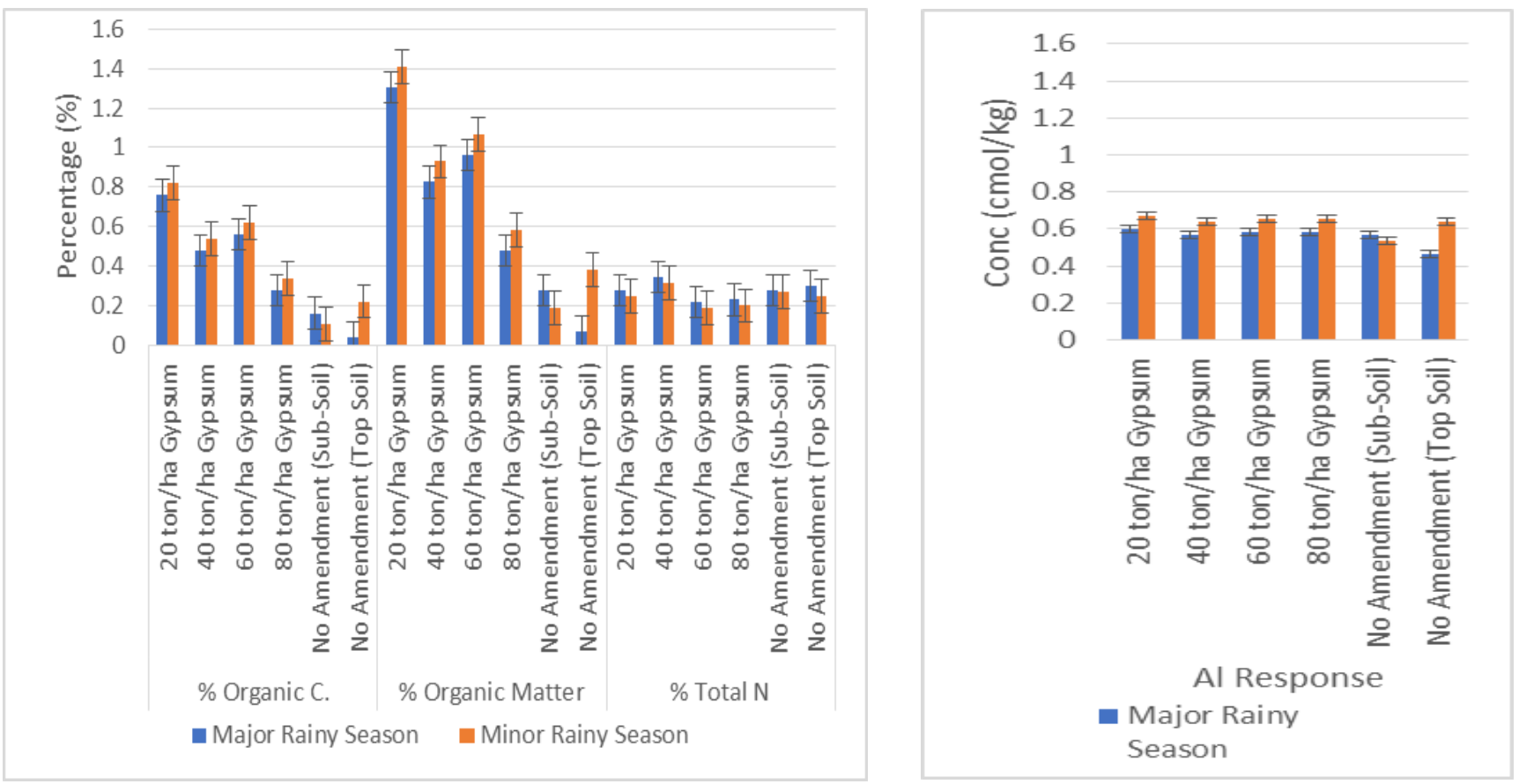

Figure 2 Effect of gypsum and seasonal variability on \% Organic C, \% Organic Matter, \% Total Nitrogen, Aluminium contents of soil

There were significant $(\mathrm{P}<0.01)$ interaction effects between gypsum treatment and season for available $\mathrm{P}, \mathrm{Ca}$ and $\mathrm{K} .20$ ton/ha gypsum provided a significantly higher available $\mathrm{P}$ of about $20 \mathrm{mg} / \mathrm{kg}$ in both seasons. Increasing gypsum application from 40 ton/ha to 80 ton/ha increased available P from $11 \mathrm{mg} / \mathrm{kg}$ to $22 \mathrm{mg} / \mathrm{kg}$ for both seasons. Subsoil control (No amendment) provided high and low available P during the major and minor seasons respectively. The topsoil control provided a high and low available P during the minor and major rainy seasons respectively (Figure 3). The significant interactions between gypsum treatment and seasons can be explained by the increased leaching and erosion of soluble ions during increased precipitation experienced in the minor rainy season and the reverse happening during the major rainy season. Thus, without amendment, available $\mathrm{P}$ in the subsoil remained high during the major season. The high available P seen in the topsoil during the minor season can be attributed to increased solubility resulting from increased precipitation during the minor rainy season. In their work, Hou et al. [27] found that high mean annual temperature negatively affected soil available $\mathrm{P}$ by decreasing organic $\mathrm{P}$ and primary mineral $\mathrm{P}$ and increasing soil sand content and that high mean annual precipitation affect available $\mathrm{P}$ by decreasing soil primary mineral P. Wu et al. [28] also found that increased rainfall intensity results in increased kinetic energy, increased raindrop detachment ability, increased effective runoff interaction and decreased runoff production, which together increases surface runoff of soil P. 


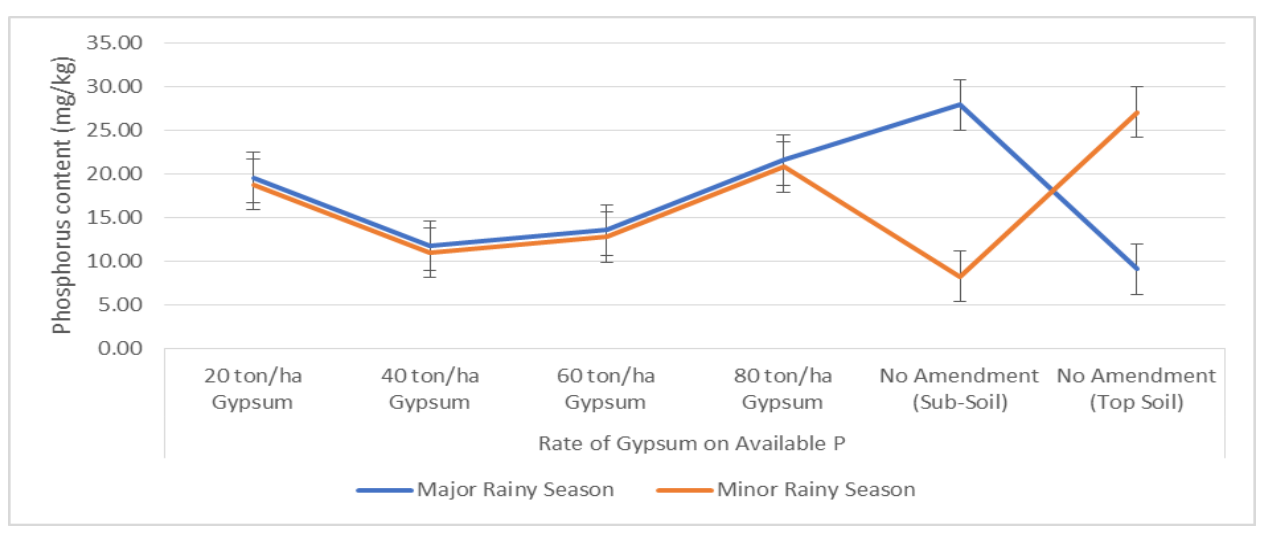

Figure 3 Effect of gypsum and seasonal variability on available P.

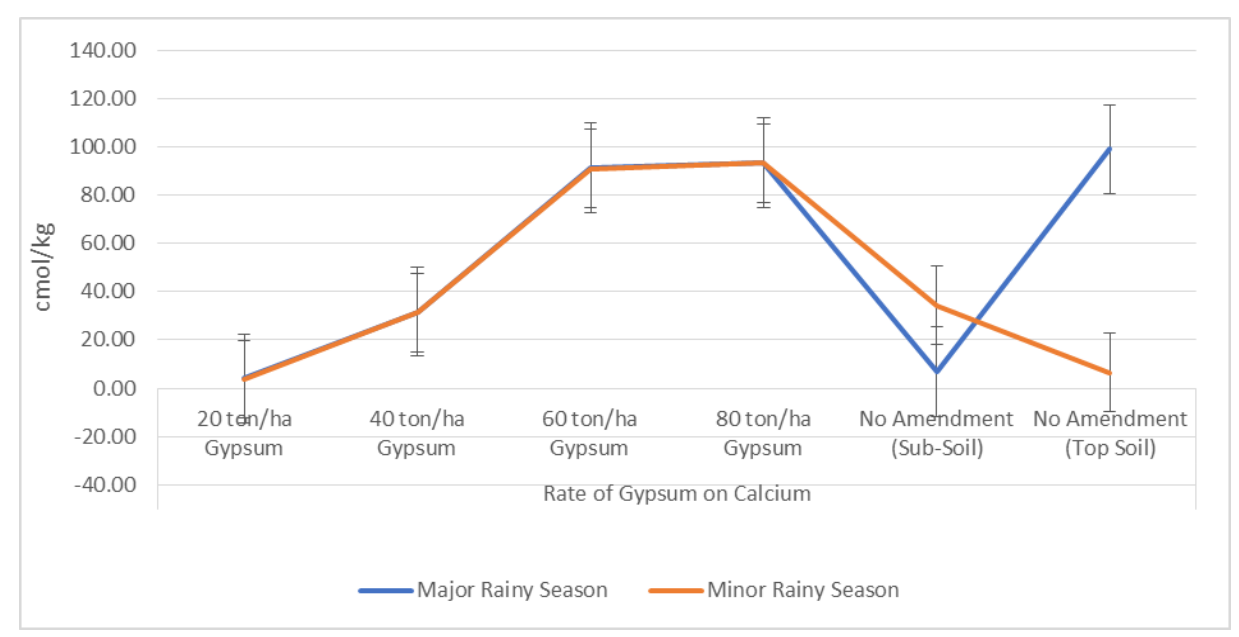

Figure 4 Effect of gypsum and seasonal variability on soil solution calcium

Increased gypsum application resulted in increased soil calcium content. 60 and 80 ton/ha gypsum produced similar soil exchangeable calcium content. Subsoil control produced a relatively high exchangeable calcium during the minor rainy seasons. The topsoil control, however, produced a high exchangeable calcium content during the major rainy season (Figure 4). The increased exchangeable calcium with increasing gypsum is attributable to the high proportion of calcium in gypsum [29]; [30]. The topsoil control's high calcium during the major season can be attributed to low precipitation received during the major rainy season which slowly enhanced the availability of exchangeable calcium in topsoil solution [31]. The low exchangeable calcium during the major rainy in the subsoil is due to the increased precipitation which resulted in the loss of calcium through leaching and runoff [32]. In their work Solly et al. [33] showed that subsoil and topsoil exchangeable calcium is largely a product of organic matter content, $\mathrm{pH}$ and presence of other exchangeable cations.

Soil $\mathrm{K}$ was significantly higher in the minor rainy season than the minor rainy season across all gypsum treatments (Figure 5). Largely, the minor season presented an adequate infiltration rate with limited runoff which resulted in increased dissolution of more potassium in solution as observed by Ullah et al. [34]. According to Rosenstock et al. [35] weather patterns and combination of microbial biomass, fine grain, potentially shielded, easily weatherable minerals, and non-structural clay interlayer bound potassium may explain seasonal cation interactions in soil. 


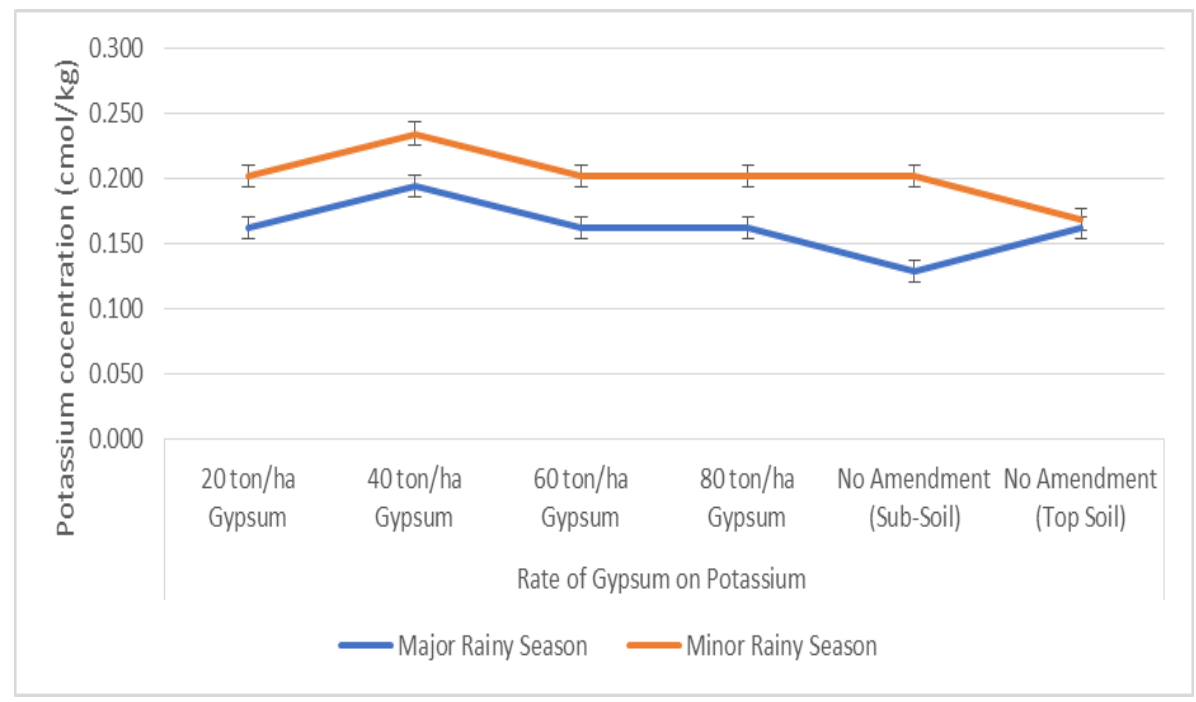

Figure 5 Effect of gypsum and seasonal variability on soil exchangeable Potassium

There was a significant interaction between gypsum treatment and seasons on exchangeable magnesium. Increasing gypsum application resulted in increased soil exchangeable magnesium in both minor and major rainy seasons (Figure 6). Subsoil and topsoil experienced low magnesium concentration during the major and minor seasons respectively. Increased exchangeable $\mathrm{Mg}$ with increasing gypsum application is attributable to the high concentration of Ca from gypsum which replaces Mg on cation exchange sites in soil [36]. Consequently, while Farina and Channon [37] argue that excessive $\mathrm{Mg}$ displacement by $\mathrm{Ca}$ in gypsum treatment deteriorate water quality, cause land degradation, lead to environmental and food security constraints in irrigation schemes and further impact crop yields negatively, HauerJákli and Tränkner [38] found that adequate Mg supply enhances net CO2 assimilation by $140 \%$, leading to a biomass increase of $61 \%$ compared to Mg deficient control plants.

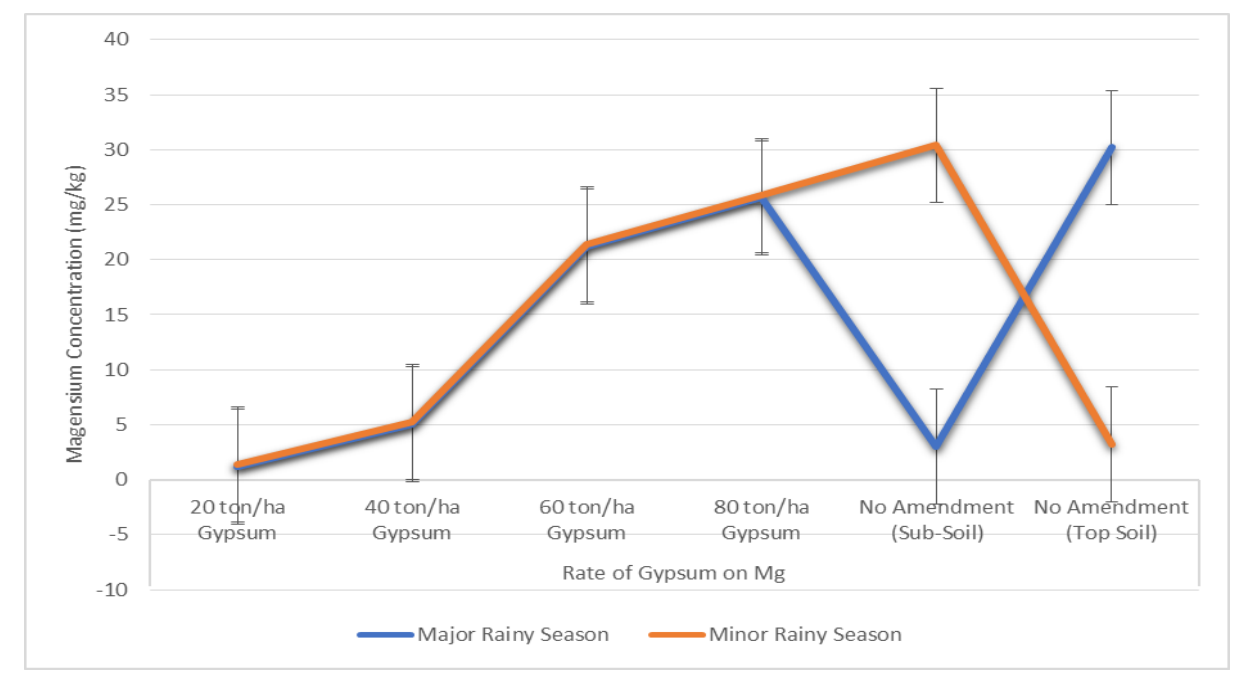

Figure 6 Effect of gypsum and seasonal variability on soil exchangeable Magnesium

There were significant interaction effects between gypsum application and seasons on $\mathrm{pH}$ during the major and minor rainy seasons. Increasing gypsum application resulted in increased $\mathrm{pH}$. Unamended subsoil was more acidic during the minor rainy season than the major rainy season. The topsoil, however, showed reduced acidity during the major rainy season than the minor rainy season (Figure 7). The increase in $\mathrm{pH}$ is due to the liming effect that results as more calcium and sulphate ions displace hydrogen and aluminium on exchangeable sites [38]; [39]. Ritchey et al. [40] also found that where sesquioxide minerals such as A1 and Fe oxides predominate, sulfate anions of gypsum displace hydroxyl groups in greater amounts than $\mathrm{Ca}$ cations displace $\mathrm{A} 1$ ions resulting in a net increase in $\mathrm{pH}$. 


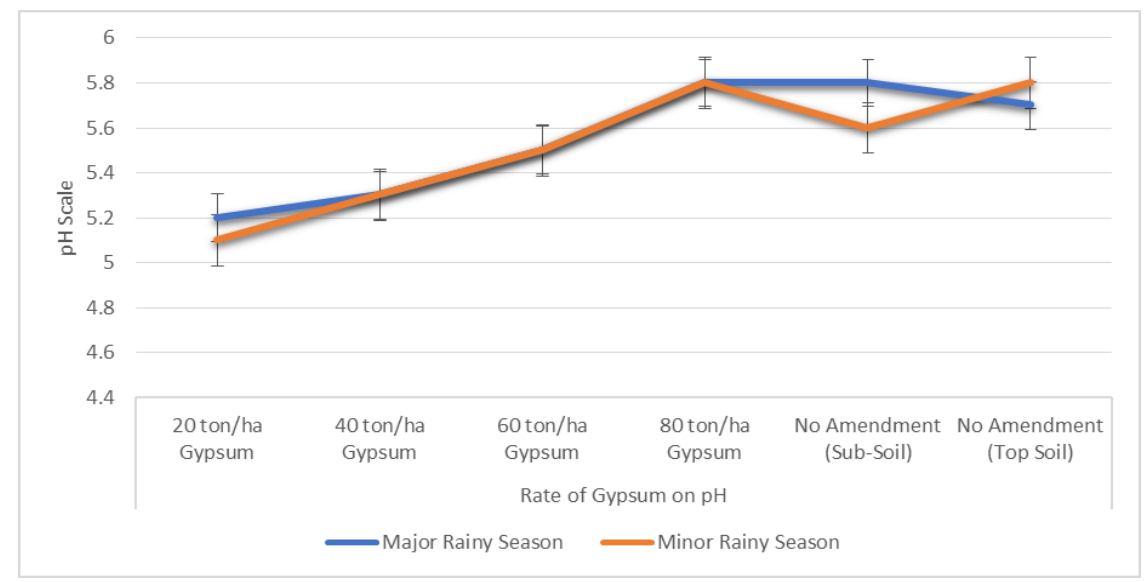

Figure 7 Effect of gypsum and seasonal variability on soil $\mathrm{pH}$

\subsection{Effect of gypsum-amended soils and seasonal variability on cucumber growth and fruit characteristics}

Interaction effect between seasonal variability and gypsum treatment on the vine length and leaf number remained significant $(\mathrm{P}<0.01)$ at second, fourth, sixth, eighth and tenth weeks after sowing $(\mathrm{WAS})$. The minor rainy season consistently gave rise to higher vine length after the second WAS. Vine length increased with increasing gypsum application while unamended subsoil produced low vine length over the growing period. Vine length for unamended topsoil was significantly higher than all gypsum-amended subsoils (Figures 8 and 9).

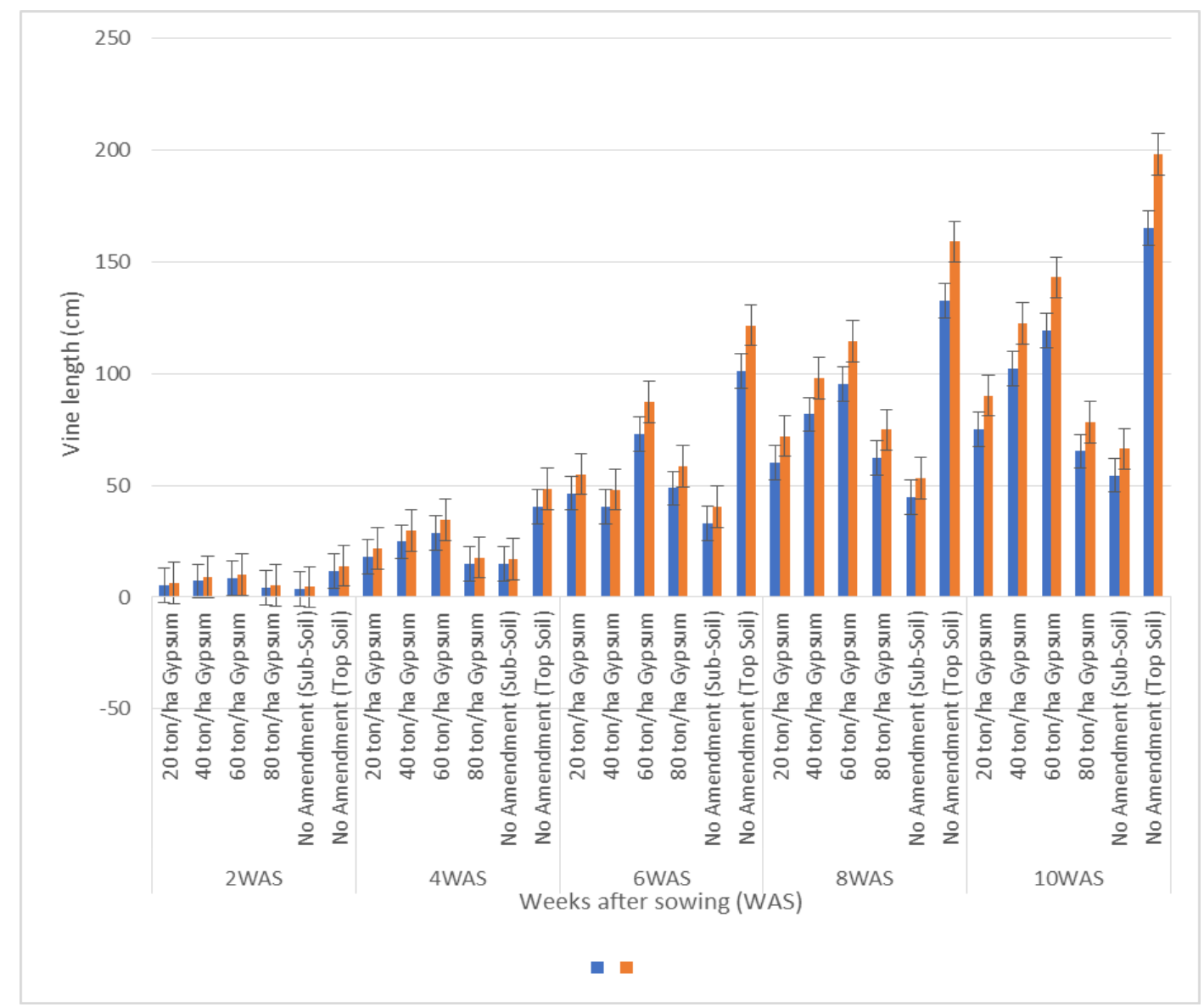

Figure 8 Effect of gypsum and seasonal variability on vine length

The increased vine length and leaf number during the minor rainy season may be due to increased precipitation and relative humidity which enhanced the vine extension and leaf production as a result of improved dissolution and xylemmediated transport of mineral nutrients from soil and translocation of photosynthetic assimilates into meristematic 
tissues. Ajibola and Amujoyegbe [41] found that soil amendment and improved water use efficiency during periods of high precipitation enhance cucumber vine length and leaf number. In an integrated nutrient management study Waskel et al. [42] found that mineral amendment of soil enhanced the vine length and number of leaves in cucumber which led to increased yield. Siddique et al. [43] and Blanchard et al. [44] found that calcium sulphate in gypsum plays a significant role in the enhancement of vine length and leaf number by strengthening cell walls to house minerals and photosynthetic assimilates during the vegetative growth phase of cucumber.

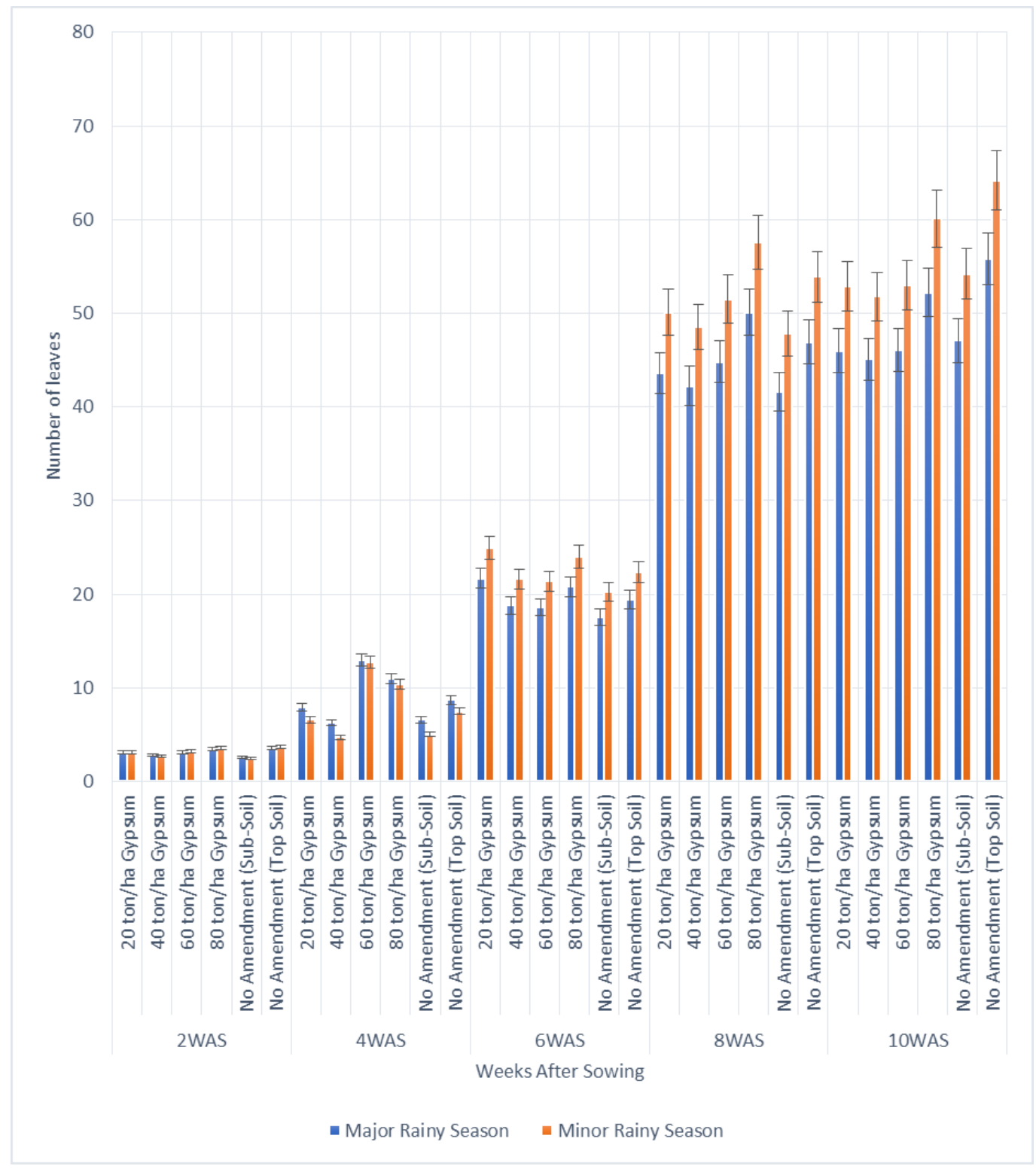

Figure 9 Effect of gypsum and seasonal variability on number of leaves

Interaction effect between gypsum treatment and seasonal variability was significant $(\mathrm{P}<0.01)$ on the number and weight of fruits. Interaction effect was not significant for fruit length (Table 6). The minor rainy season presented higher mean length, number and weight of fruits than the major rainy season. This could be due to improved assimilate deposition in the sink tissues of fruits as a result of improved dissolution and transport of water, mineral and organic materials from increased precipitation during the minor rainy season [45] Schlering et al. [46] found that the quality of cucumber crop could suffer if the right abiotic factors of water and soil nutrients are deficient. 
Table 6 Effect of gypsum amendment and seasonal variability on fruit characteristics

\begin{tabular}{|c|c|c|c|c|c|c|c|}
\hline & \multirow[t]{2}{*}{ Treatment } & \multicolumn{2}{|c|}{ Mean } & \multirow[t]{2}{*}{ S.E.D. } & \multirow[b]{2}{*}{$\begin{array}{c}\text { Treatmen } \\
\mathrm{t}\end{array}$} & \multirow[b]{2}{*}{ Season } & \multirow[b]{2}{*}{$\begin{array}{c}\text { Treatment } \\
\text { x Season }\end{array}$} \\
\hline & & $\begin{array}{l}\text { Major } \\
\text { Rainy } \\
\text { Season }\end{array}$ & $\begin{array}{c}\text { Minor } \\
\text { Rainy } \\
\text { Season }\end{array}$ & & & & \\
\hline \multirow{7}{*}{$\begin{array}{c}\text { Fruit } \\
\text { length } \\
(\mathrm{cm})\end{array}$} & 20 ton/ha Gypsum & 7.80 & 9.36 & 8.58 & \multirow[t]{7}{*}{$0.479^{* *}$} & \multirow[t]{7}{*}{$0.277^{* *}$} & \multirow[t]{7}{*}{0.678} \\
\hline & 40 ton/ha Gypsum & 8.31 & 9.97 & 9.14 & & & \\
\hline & 60 ton/ha Gypsum & 8.96 & 9.98 & 9.47 & & & \\
\hline & 80 ton/ha Gypsum & 7.20 & 8.64 & 7.92 & & & \\
\hline & No Amendment (Sub-Soil) & 6.20 & 7.44 & 6.82 & & & \\
\hline & No Amendment (Topsoil) & 9.10 & 9.59 & 9.34 & & & \\
\hline & Mean & 7.93 & 9.16 & 8.55 & & & \\
\hline \multirow{7}{*}{$\begin{array}{l}\text { No. of } \\
\text { Fruits per } \\
\text { Plant }\end{array}$} & 20 ton/ha Gypsum & 3.30 & 3.96 & 3.63 & \multirow[t]{7}{*}{$0.1044^{* *}$} & \multirow[t]{7}{*}{$0.0603^{* *}$} & \multirow[t]{7}{*}{$0.1476^{* *}$} \\
\hline & 40 ton/ha Gypsum & 4.11 & 5.19 & 4.65 & & & \\
\hline & 60 ton/ha Gypsum & 4.30 & 5.16 & 4.73 & & & \\
\hline & 80 ton/ha Gypsum & 3.10 & 3.72 & 3.41 & & & \\
\hline & No Amendment (Sub-Soil) & 2.20 & 2.64 & 2.42 & & & \\
\hline & No Amendment (Topsoil) & 5.30 & 6.36 & 5.83 & & & \\
\hline & Mean & 3.72 & 4.51 & 4.11 & & & \\
\hline \multirow{7}{*}{$\begin{array}{c}\text { Fruit } \\
\text { Weight } \\
\text { (kg) }\end{array}$} & 20 ton/ha Gypsum & 0.03 & 0.04 & 0.03 & \multirow{7}{*}{$\begin{array}{c}0.001749 \\
* *\end{array}$} & \multirow[t]{7}{*}{$0.00101^{* *}$} & \multirow[t]{7}{*}{$0.002473^{* *}$} \\
\hline & 40 ton/ha Gypsum & 0.08 & 0.10 & 0.09 & & & \\
\hline & 60 ton/ha Gypsum & 0.08 & 0.10 & 0.09 & & & \\
\hline & 80 ton/ha Gypsum & 0.08 & 0.10 & 0.09 & & & \\
\hline & No Amendment (Sub-Soil) & 0.05 & 0.06 & 0.06 & & & \\
\hline & No Amendment (Topsoil) & 0.11 & 0.13 & 0.12 & & & \\
\hline & Mean & 0.07 & 0.09 & 0.08 & & & \\
\hline
\end{tabular}

S.E.D. Standard Error of the Differences of mean; **Mean significant at $1 \%$ probability level

\subsection{Effect of gypsum-amended soils and seasonal variability on the concentration of heavy metals in cucumber fruits}

Interaction effect between gypsum treatment and seasonal variability was not significant for arsenic (As), cadmium $(\mathrm{Cd})$, mercury $(\mathrm{Hg})$ and lead $(\mathrm{Pb})$. Seasonal effects were however significant for all heavy metals considered. Apart from lead $(\mathrm{Pb})$, treatment effects on heavy metals were not significant. The major rainy season gave a significantly higher lead content (Figure 10). On the whole, lead ( $\mathrm{Pb}$ ) concentration in cucumber was significantly higher (above $8 \mathrm{mg} / \mathrm{kg}$ ) during the major rainy season while arsenic (As), cadmium (Cd) and mercury (Hg) remained below $2 \mathrm{mg} / \mathrm{kg}$ across treatments and seasons. The mean concentration of heavy metals in cucumber exceeded WHO/FAO permissible limits (Table 5). Similarly, in a baseline study of heavy metals in soils and plants ahead of oil exploration in Ghana, FosuMensah et al. [47] found that concentrations of arsenic, cadmium and lead in soils and plants exceeded WHO/FAO permissible limits. Although different literature present different reports on permissible limits from WHO/FAO standards, it is better settle for less risky limits reported in literature but the question that remains is whether heavy metals found in soils beyond the permissible limits are naturally occurring or as a result of contamination from external sources. Further clarification and studies on heavy metals' permissible limits in soils, plants and their management need serious consideration. For example, what is the maximum allowable concentration of heavy metal in agricultureintended soil beyond which remediation would be required and at what permissible concentration of heavy metal in 
crops should be regarded as poisonous for consumption and are there historical studies of spatial distributional patterns of heavy metals for comparative studies?

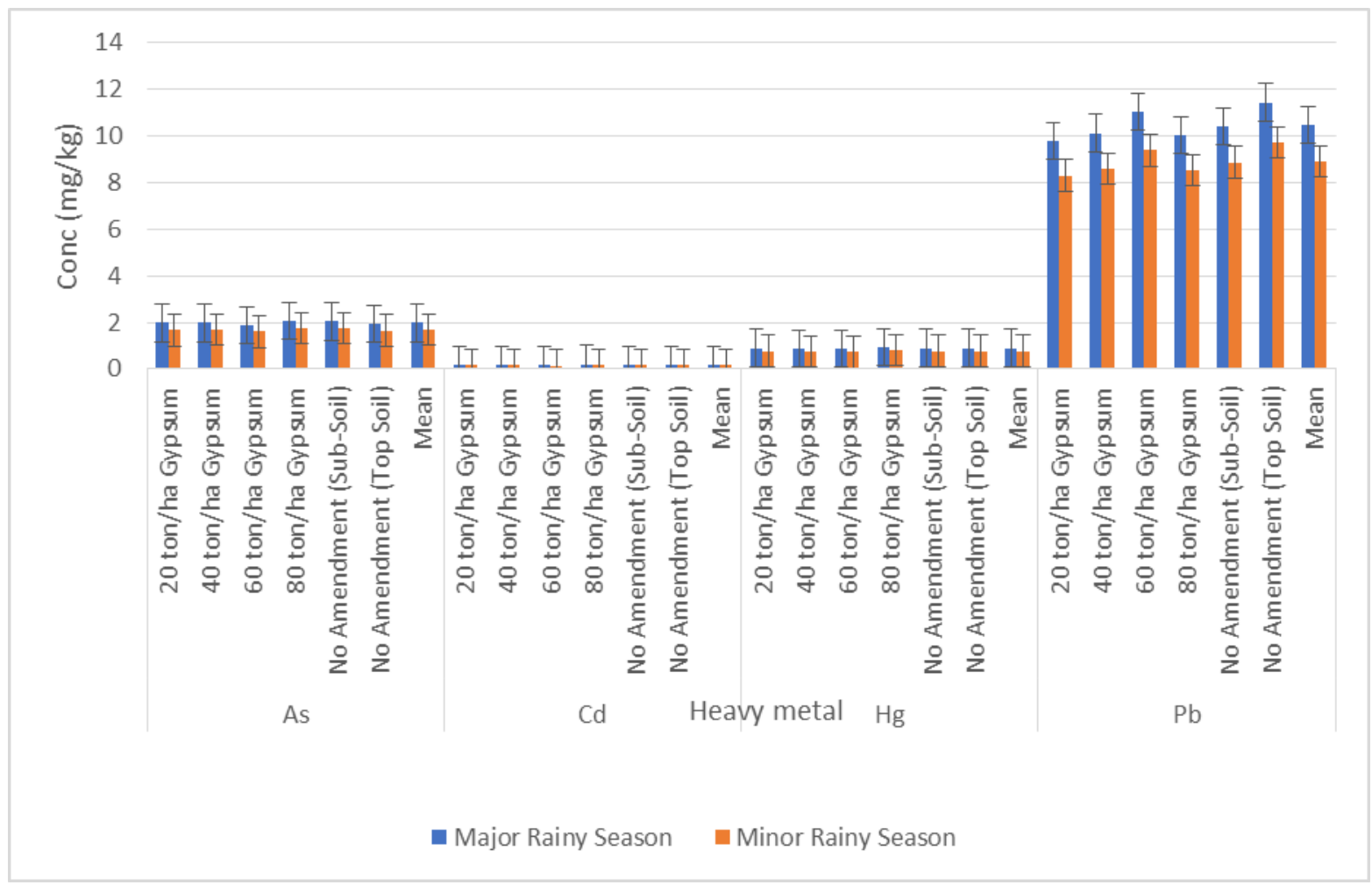

Figure 10 Effect of gypsum and seasonal variability on heavy metal toxicity in cucumber

\section{Conclusion}

The effect of gypsum amendment and seasonal variability on exposed subsoil quality, growth, yield and toxicological responses of Cucumber has been evaluated. The study has shown that exposed subsoils can be amended with gypsum produced from ARD water treatment facilities for agricultural activities. Gypsum applied at 20 ton/ha, 40 ton/ha, 60 ton/ha, 80 ton/ha, 0 ton/ha subsoil and 0 ton/ha topsoil in two rainy seasons (major and minor) resulted in significant interaction effects on soil chemical characteristics such as \% organic carbon, \% organic matter, \% total nitrogen, aluminium, available phosphorus, exchangeable calcium, exchangeable potassium, exchangeable magnesium, and soil $\mathrm{pH}$. Significant interaction effects were also observed between gypsum treatment and seasonal variability on cucumber growth and fruit characteristics (vine length, leaf number, number of fruits per plant and fruit weight) and heavy metal concentration. Interaction effects on cucumber growth (vine length and number of leaves) and fruit characteristics (number of fruits per plant and fruit weight) were significantly higher during the minor rainy season. Lead (Pb) concentration was pronounced (above $8 \mathrm{mg} / \mathrm{kg}$ ) during the major rainy season. Concentrations of Arsenic (As), Cadmium (Cd) and Mercury (Hg) remained below $2 \mathrm{mg} / \mathrm{kg}$ across treatments during the minor and major rainy season. There were, however, no significant differences between gypsum-treated and control plots on heavy metal content of cucumber. In line with SDGs 2, 3, 12, 13, 14 and 15 which enjoins all to contribute to ending hunger, achieving food security, promote sustainable agriculture and food safety in an environment characterized by low ecological footprint it is conclusive that exposed subsoils can also be amended for agricultural purposes if weather patterns are supportive. Amendment of exposed subsoils with gypsum will limit the resource input needed to lime acidic soils as a result of natural or anthropogenic increments in soil acidity or from acid mine or acid rock drainage. Further and long-term studies are needed to establish the risks associated with prolonged production and consumption of crops cultivated on soils with high heavy metal content vis-à-vis the phytochemical interactions of plants in the environment and living tissues. Multi-locational subsoil evaluation with gypsum amendments is further recommended to shed more light on subsoil behaviour with gypsum application. 


\section{Compliance with ethical standards}

\section{Acknowledgments}

The authors are thankful for the assistance provided by Agency for Health and Food Security for the sponsorship of this study. The assistance provided by Newmont Environmental Sustainability Division for allowing their site to be used is deeply appreciated.

\section{Disclosure of conflict of interest}

Authors have declared that no competing interests exist.

\section{References}

[1] Duncan C, Good MK, Sluiter I, Cook S, Schultz NL. Soil reconstruction after mining fails to restore soil function in an Australian arid woodland. Restoration Ecology. 2020; 28(S1): A35-A43.

[2] Miller VS, Naeth AM. Amendments to Improve Plant Response Under Stimulated Water Limited Conditions in Diamond Mine Anthroposols. Canadian Journal of Soil Science. 2020; 05: 1-31.

[3] USDA-NRCS. Inherent Factors Affecting Bulk Density and Available Water Capacity. 1998; (Issue 2).

[4] Skousen JG, Ziemkiewicz PF, McDonald LM. Acid mine drainage formation, control and treatment: Approaches and strategies. Extractive Industries and Society. 2019; 6(1), 241-249.

[5] Gibson G, Fazel M, Chesters SP. Cleaning calcium sulfate in mine water membranes. Proceedings of the World Congress on Mechanical, Chemical, and Material Engineering. 2019; 1-9.

[6] González-Terán G, Gómez-Merino F, Trejo-Téllez L. Effects of Silicon and Calcium Application on Growth, Yield and Fruit Quality Parameters of Cucumber Established in a Sodic Soil. Acta Scientiarum Polonorum Hortorum Cultus. 2020; 19(3): 149-158.

[7] World Bank. Country Environmental Analysis (W. B. Group (ed.). 2020; Issue April). World Bank Publications.

[8] Ofori-Sarpong G. Acid Drainage Potential of Rocks in South-Western Ghana. International Journal of Environmental Protection and Policy. 2019; 7(1): 9.

[9] Ferring D, Hausermann H. The Political Ecology of Landscape Change, Malaria, and Cumulative Vulnerability in Central Ghana's Gold Mining Country. Annals of the American Association of Geographers. 2019; 0(0): 1-18.

[10] Raut Y, Shedekar V, Islam K, Gonzalez J, Watts D, Dick W, Flanagan D, Fausey N, Batte M, Reeder R, VanToai T. Soybean yield response to gypsum soil amendment, cover crop, and rotation. Agricultural \& Environmental Letters. 2020; 5(1): 2-7.

[11] Ngan SL, How BS, Teng SY, Promentilla MAB, Yatim P, Er AC, Lam HL. Prioritization of sustainability indicators for promoting the circular economy: The case of developing countries. Renewable and Sustainable Energy Reviews. 2019; 111: 314-331.

[12] Asante K, Essilfie ME, Manu-Aduening J. Influence of Different Rates of Fertilizer and Biochar on Growth and Yield of Carrot (Daucus carota) in the Forest-Savannah Transitional Zone of Ghana. Asian Journal of Research in Crop Science. 2020; 5(1): 21-39.

[13] Faloye OT, Ajayi AE, Alatise MO, Ewulo BS, Horn R. Nutrient uptake, maximum yield production, and economic return of maize under deficit irrigation with biochar and inorganic fertiliser amendments. Biochar. 2019; 1(4): 375-388.

[14] Bray RH, Kurtz. Soil Survey Standard Test Method-Available Phosphorus: Bray No 1 Extract. Sustainable Natural Resources. 1945; 1: 1-4.

[15] Tahtouh J, Mohtar R, Assi A, Schwab P, Jantrania A, Deng Y, Munster C. Impact of brackish groundwater and treated wastewater on soil chemical and mineralogical properties. Science of the Total Environment. 2019; 647: 99-109.

[16] Cater M, Parkin G, Culley J, Hao X, Ball, B. Soil Density and Porosity. In Soil Sampling and Methods of Analysis, Second Edition. 2007.

[17] Wilson D, Ek A. Minnesota Forestry Research Notes. Minnesota Forestry Research Notes. 2013; 296 : 1-5. 
[18] Osmani M, Bani A, Hoxha B. Heavy Metals and Ni Phytoextractionin in the Metallurgical Area Soils in Elbasan. Albanian Journal of Agricultural Science. 2015; 14(4): 414-419.

[19] Abbas M, Parveen Z, Iqbal M, Iqbal S, Bhutto R. Monitoring of toxic metals (Cadmium, Lead, Arsenic and Mercury) in vegetables of sindh , Pakistan. Kathmandu university journal of science, engineering and technology. 2010; 6(2): 60-65.

[20] Ibáñez AIBLD. Joint fao/who food standards programme codex alimentarius commission. 1993; 26(2): 78-79.

[21] Palmer, S. Recommended dietary allowances, tenth edition. In European Journal of Clinical Nutrition. $1990 ;$ Vol. $44(2)$.

[22] Veiga M, Baker R. Protocols for environmental and health assessment of mercury released by Artisanal and Small Scale Miners. Report to the Global Mercury Project: Removal of barriers to introduction of cleaner Artisanal Gold Mining and extraction technologies. 2004.

[23] Wong VNL, Dalal RC, Greene RSB. Carbon dynamics of sodic and saline soils following gypsum and organic material additions: A laboratory incubation. Applied Soil Ecology. 2009; 41(1): 29-40.

[24] Abdel-Fattah MK. Role of gypsum and compost in reclaiming saline-sodic soils. IOSR Journal of Agriculture and Veterinary Science. 2012; 1(3): 30-38.

[25] Botha AM, Kunert KJ, Maling'a J, Foyer CH. Defining biotechnological solutions for insect control in sub-Saharan Africa. Food and Energy Security. 2020; 9(1): 1-21.

[26] Jansson JK, Hofmockel KS. Soil microbiomes and climate change. Nature Reviews Microbiology. 2020; 18(1): 3546.

[27] Hou E, Chen C, Luo Y, Zhou G, Kuang Y, Zhang Y, Heenan M, Lu X, Wen D. Effects of climate on soil phosphorus cycle and availability in natural terrestrial ecosystems. In Global Change Biology. 2018; 24(8).

[28] Wu L, Yen H, Ma X. Effects of particulate fractions on critical slope and critical rainfall intensity for runoff phosphorus from bare loessial soil. Catena. 2021; 196(October): 104935.

[29] Gabriel CA, Cassol PC, Simonete MA, Pfleger P, Mumbach GL. Lime and Gypsum Applications on Soil Chemical Attributes and Initial Growth of Eucalyptus. Floresta. 2018; 48(18): 573-582.

[30] Iii JAA, Jr JPB, Harris GH, Grey TL, Cabrera M. Effect of Gypsum Application Rate, Soil Type , and Soil Calcium on Yield , Grade and Seed Quality of Runner Type Peanut Cultivars. Peanut Science. 2017; 44: 13-18.

[31] He X, Zheng Z, Li T, He S, Zhang X, Wang Y, Huang H, Yu H, Liu T, Lin C. Transport of colloidal phosphorus in runoff and sediment on sloping farmland in the purple soil area of south-western China. Environmental Science and Pollution Research. 2019; 26(23): 24088-24098.

[32] Thorsteinsson B, Jóhannesson GH, Thorlacius A, Gudmundsson T. Precipitation, runoff and nutrient losses from cultivated Histosols in western Iceland. Icelandic Agricultural Sciences. 2019; 32(1): 61-74.

[33] Solly EF, Weber V, Zimmermann S, Walthert L, Hagedorn F, Schmidt MWI. A Critical Evaluation of the Relationship Between the Effective Cation Exchange Capacity and Soil Organic Carbon Content in Swiss Forest Soils. Frontiers in Forests and Global Change. 2020; 3(September): 1-12.

[34] Ullah A, Ali M, Shahzad K, Ahmad F, Iqbal S, Habib Ur Rahman M, Ahmad S, Mazhar Iqbal M, Danish S, Fahad S, Alkahtani J, Soliman Elshikh M, Datta R. Impact of seed dressing and soil application of potassium humate on cotton plants productivity and fiber quality. Plants. 2020; 9(11): 1-13.

[35] Rosenstock NP, Stendahl J, Van Der Heijden G, Lundin L, McGivney E, Bishop K, Löfgren S. Base cations in the soil bank: Non-exchangeable pools may sustain centuries of net loss to forestry and leaching. Soil. 2019; 5(2): 351366.

[36] Khorshidi M, Lu N. Determination of Cation Exchange Capacity from Soil Water Retention Curve. Journal of Engineering Mechanics. 2017; 143(6): 04017023.

[37] Farina MPW, Channon P. Acid-Subsoil Amelioration: II. Gypsum Effects on Growth and Subsoil Chemical Properties. Soil Science Society of America Journal. 1988; 52(1): 175-180.

[38] Hauer-Jákli M, Tränkner M. Critical leaf magnesium thresholds and the impact of magnesium on plant growth and photo-oxidative defense: A systematic review and meta-analysis from 70 years of research. Frontiers in Plant Science. 2019; 10(June): 1-15. 
[39] Scharfstein M, Gaurf. Remediation Mea-sures for Arsenic Pollution of Soil. Journal of Chemical Information and Modeling. 2020; 53(9): 1689-1699.

[40] Ritchey KD, Korcak RF, Feldhake CM, Baligar VC, Clark RB. Calcium sulfate or coal combustion by-product spread on the soil surface to reduce evaporation, mitigate subsoil acidity and improve plant growth. Plant and Soil. 1996; 182(2): 209-219.

[41] Ajibola OV, Amujoyegbe BJ. Effect of Seasons, Mulching Materials, and Fruit Quality on a Cucumber (Cucumis sativus L.) Variety. Asian Journal of Agricultural and Horticultural Research. 2019; 3(2): 1-11.

[42] Waskel S, Jatav SK, Singh SS. Effect of Integrated Nutrient Management on Growth and Yield attributes of Brinjal. International Journal of Current Microbiology and Applied Sciences. 2019; 8(11): 1849-1853.

[43] Siddique S, Ayub G, Nawaz Z, Zeb S, Khan FS, Ahmad N, Khan A, Rauf K. Enhancement of growth and productivity of cucumber (Cucumis sativus) through foliar application of calcium and magnesium. Pure and Applied Biology. 2017; 6(2): 402-411.

[44] Blanchard C, Wells DE, Pickens JM, Blersch DM. Effect of pH on cucumber growth and nutrient availability in a decoupled aquaponic system with minimal solids removal. Horticulturae. 2020; 6(1): 1-12.

[45] Smith MR, Rao IM, Merchant A, Smith MR. Source-Sink Relationships in Crop Plants and Their Influence on Yield Development and Nutritional Quality. Frontiers in Plant Science. 2018; 9(December): 1-10.

[46] Schlering C, Schweiggert R, Dietrich H, Frisch M, Zinkernagel J. Effects of moderately-reduced water supply and picking time on the chemical composition of pickling cucumber (cucumis sativus L.) in open field cultivation. Agronomy. 2020; 10(8): 1-21.

[47] Fosu-Mensah BY, Ofori A, Ofosuhene M, Ofori-Attah E, Nunoo FKE, Darko G, Tuffour I, Gordon C, Arhinful DK, Nyarko AK, Appiah-Opong, R. Assessment of heavy metal contamination and distribution in surface soils and plants along the west coast of Ghana. West African Journal of Applied Ecology. 2018; 26: 167-178. 